\title{
ECO-CRITICISM: HUIMAN AND PHYSICAL WORLD RELATIONSHIP IN GULLIVER'S TRAVELS.
}

KEY WORDS: Sea, Animals, Race, and Landscapes

\section{Arunakumari S}

Assistant Professor, DWH-FLS, JSS Academy of Higher Education and Research Mysore.

This research paper studies a relationship between literature and the physical world is known as eco-criticism. In English Literature Eco criticism refers to specific types of texts. The word "Eco-criticism" depicts the images of nature, forests, animals, birds, seasons, rivers, cities, and flowers. In addition to novels, eco-criticism contains drama, poetry, travel books, cartoons, fables, short stories, movies, songs, games, children's stories and this is an Old English literature concept that's still trendy today, from Beowulf to the present writer. Animals have existed from the beginning of history. That means animals were depicted in literature since the start of history. When Christianity was introduced to the world, the Holy Bible says God created birds, animals first, at last man, it is called natural theology, and also nature is divine. Critics said, for western people's experience on earth is different from other people on the earth,Westerners believed in "Nature's uncountable sounds... have been deafening." The contrast, which is promoted by social anthropology of animism, highlights an element in contemporary society at large connection towards the physical world which is also gradually becoming a central focus when it comes to the environment."The natural world is a social and cultural category." In animistic traditions, those few who believe that perhaps the natural environment is inspirited, not only human beings, and also for life of animals, trees, and even "inert" entities like stones. Rivers and seas are seen as articulate and sometimes intelligible beings, capable of communicating and interacting with humankind for good and bad. There is also the language of animals, air, horses, lions, seas, trees, in the novel of Gulliver's Travels and in this novel animal world also have politics, rules of their society, they won't allow outsiders, and have own food, medicine, the different body structure of animals, these are the things we can see in Jonathan Swift's Gulliver Travels in all four books.

\section{INTRODUCTION}

This Paper investigates literature evolving views of interactions with humans, animals, and the physical world in England during the long 1880 s, including history and critical study. Methods of depicting plants and animals hybrids, and also moral difficulties posed by human exploitation of other creatures, remain questions left unanswered. The early ethnographic literature' equating of non-European races with nonhuman animals, as well as the attempt to differentiate the complete humans form in the completely non - human animals the works of Mary Shelly and Percy Shelley, as well as Gulliver's Travels, emerged as significant readings for such research. In the Hebrew Bible, in the Garden of Eden, Eve and Serpent spoke each other so animals and literature are old, in Greek classical work Odyssey, From Geoffrey of Chaucer to Shakespeare era in their works, Sea and voyage to different continent and country, horse, sea, ship, birds, animals, nature, garden, the forest used as symbols, so human and non-human world frequently appeared in literature as a binary opposition. A power humans give themselves to rule on over the natural world has allowed us to exploit animals for consumption clothing, equipment, transportation, war, work, sports, devotion, including, of naturally, artwork and exploitation of nature through colonization all are common.

In Robinson Crusoe (1719) by Daniel Defoe is informative throughout this respect, because it narrates the tale of a shipwreck, Crusoe should rediscover his existence by trying to wrestle from the natural world its means to fulfill his basic human needs, while also reestablishing his differentiation from the natural world and claiming the power granted by western society to regulate it. Critics have interpreted Defoe's fiction like an allegorical for the foundation of political sovereignty based on the concept of colonial protestant individualism, but little attention has been paid to the fact that Crusoe's process of reinvention is entirely based on the domestication of animals-goats, cats, and a parrot-and his use of them for food, clothing, shelter, and companionship. Nature was, of course, a constant referent for the Romantics, although it is a landscape that is weirdly bereft of animal life, despite the presence of birdsong in its poetry. Romantic poetry inhabits a mental landscape in which the mind, captivated by what it sees in nature, produces a song through recall that, though being modeled after the voice of a nightingale, is entirely creative imagination.
In Dublin, Ireland, Jonathan Swift was born in 1667 to English parents. Sad to say, his father died before he was born, and the family had to rely on relatives for financial assistance. Following his school education and graduation, he served as Sir William Templeton's private secretary for many years. He returned to Ireland owing to illness, but due to a lack of a job, he returned to his previous position. Swift wrote several of his best-renowned satires, such as "A Tale of the Tub" and "The Battle of the Books", in 1699, but they were only published in 1704. Gulliver's Travels (originally published between 1721 and 1725) was a parody mostly on contemporary political situations between both the Whigs and the Tories and was published in 1726. Even though he wrote various works during the thirties, his health began to fail him, and he deteriorated until he dies on October 19, 1745. Swift lived in a time even though there were many political conflicts and theological disputes, especially well within the Churches. Jonathan Swift with his peers, such as Alexander Pope, Richard Steele, and Joseph Addison, used their work to mock famous institutions and political figures.

Lemuel Gulliver was a well-educated sailor who published his memories of 4 travels to far-flung regions of the earth to contribute to human thought. These will be discussed in detail in Gulliver's Travels is comprised of four books. Gulliver is drowned on an unnamed island near Sumatra in Book I, on his first voyage to Lilliput, and awakens to discover himself enslaved by a race of humans six inches tall. Those who assault him using arrows and spears when he moves his head or shout, but they cease when he remains silent. Thousands of people feeding Gulliver bowls of food and water after he makes a sign that he is hungry and thirsty. Gulliver's flawless behavior impresses the Emperor of Lilliput. After some series of adventures, Gulliver encounters the people of Blefuscu, Lilliput's adversaries, and comes back.

Gulliver is abandoned by his shipmates in Book II in such a region where even the occupants are twelfth times his shape. They maintain him as a pet and consider him a natural phenomenon. In Book II, the scale is flipped. Gulliver had been treated badly by the Lilliputians when he first arrived, but now the giants are sympathetic to him. Gulliver is kidnapped by thieves and abandoned on a group of small islands in Book III. He is transported to Laputa, a floating island populated by individuals concerned with abstract sciences who rule Balnibarbi's territory. Gulliver travels to 
Glubbdrubdrib, the Magician's Island, through Balnibarbi. He next travels to Luggnagg, wherein he encounters the Struldbrugs, a race doomed to eternal mental instability.

He is the Captain of a ship in Book IV, so he's the victim of a rebellion. He is left on a beach but also encounters the Houyhnhnms, an aristocratic race of horses. Jonathan Swift then finds the Yahoos, who, despite their human appearance, he believes to be the most unpleasant creatures he has ever encountered. The Houyhnhnms, on either hand, appeared to just be perfect animals, and Gulliver grows to appreciate their style of living. Those who are polite and philosophical, in contrast to Book III's ludicrous and vengeful Lilliputians, hideous Brobdignagians, and intellectual freaks. The Houyhnhnms, on the other hand, view Gulliver as a sort of Yahoo, a viewpoint with something he is forced to concede. Gulliver is set to leave for England after being exiled from his homeland, where he spends his time talking to his horses and trying to reform his kingdom's citizens.

\section{Sea}

The symbol sea from Bible to contemporary literature used by writers. In Shakespeare's plays sea is a symbol of money, business, and colonial power. The sea performs a vital position in Homer's classic book The Odyssey, which depicts the ten-year journey of its Greek hero Odysseus all through the sea, confronting sea giants and a long journey. According to Ernest Hemingway in his "The old man The Sea", a human's ability to prove his worth was best demonstrated in solitude. The sea represents the Universe in the story, as well as Santiago's alienation from it. Santiago's final task will be faced at sea, with no support and no acknowledgment. In this respect, the work is a literary representation of Naturalism. In contemporary year's author Joseph Conrad has written many sea-themed works, notably "Lord Jim" and "The Nigger of the 'Narcissus" based on his understanding as a business sea captain.

Gulliver sets out on four different adventures, all of these seem to have begun with a shipwreck and end with either a dramatic escape or a pleasant decision that it is time for Gulliver to depart. The societies with whom Gulliver interacts allow him (as well as the readers) to reflect more deeply on his civilization. Lemuel Gulliver is introduced as a fictitious figure that completes his family, schooling, and marriage at the opening of the first book. Gulliver's flight to something like an island wherein people are just six inches in length reveals a realistic portrayal of a true voyage, as well as the expedition's symbolic meaning. The first voyage he starts and Swift wrote

"I accepted an advantageous offer from Captain William Prichard, master of the Antelope, who was making a voyage to the South Sea.

We set sail from Bristol, May 4, 1699, and our voyage was at first very prosperous".

All the four books started in sea and ended also in sea with the different places of the world. So water is a sign of life and death, it portrayed in this novel.

\section{Animals}

Soldiers used to ride horses to battles in ancient time, but only one horse in particular: the so-called Trojan horse that, such as literature, was still a Greeks creation, in this story how soldiers upon coming back home from the Trojan war, the Greeks deceived the Trojans in hiding inside a wooden horse they claimed to have built-in homage of Greek goddess Athena. Influenced that perhaps the Greeks had fled their shores to defeat, the Trojans brought the horse inside their castle as a memento for their victory, which they would then continued to enjoy with disastrous results as Greek soldiers came out from horse and ruin the celebration. Geoffrey of Chaucer's "The Canterbury Tales: General Prologue", in this book all the characters used horse for travel. Indeed, the domestication of the horse is one of the most important aspects of human civilization, and the changing relationship between horse and human can be traced throughout history. Unicorn also a type of horse used in the play "The Glass Menagerie" by Arthur Miller. Not only horses and also other animals and birds had used in literature like birds, dogs, rabbits, tiger, loin, etc.

Animals used in children's literature example fables, fairy tales, and songs and also used in the political way of writings example Swift's Gulliver's Travels and George Orwell's Animal Farm as speaking animals, shows they have their society, culture, rules, and practice. In Albert Camus's novel "The Plague" rats had used likes swift's Gulliver's Travels animals. The concept of animality used in $17^{\text {th }}$ and $18^{\text {th }}$-century literature, Keith Thomas noted

"Men attributed to animals the natural impulses they most feared in themselves - ferocity, gluttony, sexuality - even though it was men, not beasts, who made war on their species, ate more than was good for them, and were sexually active all year round.

it was as a comment on human nature that the concept of "animality"was devised".(1996,40-41,emphasis in original)

"The Jungle Books" by Rudyard Kipling can be viewed through the lens of colonialism's capitalist paradigm. Kipling's Mowgli tales, which are very well known, depict a natural or naturalized setting in which animals appeared to be behaving like beasts for an individual human listener. Mowgli's hybridity is examined from the perspective of zoological taxonomy, which, the character we can see in Gulliver's Travels as a character Lemuel Gulliver.

The Lilliputians, according to Gulliver, are competent and practical engineers because they were able to create and build gigantic vehicles in just a few hours. The picture of Gulliver rising tall underlines the disparity and his and the Lilliputians' viewpoints. He thinks he's average, and they think he's tiny. Those appear normal to them, even though he's a monster. When he entered small people world and try to humiliate the queen and left this place because of punishment. It shows he is an outsider try to colonize them.

In the second book, he is a tiny man, but all other birds, animals, and people of their very big, the Adventure series journey begin successfully, but still, the ship is damaged by a storm north of Madagascar, sending them on the route into unfamiliar oceans. They unload and divide to search for water when they eventually locate an island. Whenever a large "giant" scared his comrades towards sailing back to the island without him, Gulliver gets abandoned alone. Gulliver continues his journey further inside the island and notices that he must be encircled by gigantic grass and crops. This lead to the reader how Gulliver is wrapped in a handkerchief and brought home by the farmers.

In the second book, farmer's home Gulliver is afraid of the cats, and the baby nearly kills him. The farmer's lady covers him inside her napkin just after the meal. Gulliver is assaulted with two rats the size of "mastiffs" while there, but he survives by killing one with his knife (the other is scared away). Gulliver's reputation grows throughout the city, and a miserly neighbor of the Brobdingnagian farmer suggests him to make money by presenting Gulliver "as just a view" there in the marketplace. The farmer happily takes Glumdalclitch with Gulliver to the marketplace the next day, despite Glumdalclitch's fears that Gulliver will be damaged by probing strangers it shows the Zoo cultural and slave system. Gulliver explains the most irritating insects he encounters every day. The dwarf of the Brobdingnagian princess enjoyed punishing him. He nearly drowned Gulliver in a jug of cream and once stuck him in the hole of a bone. Gulliver also was troubled by insects, that are enormous in comparison to him as well urinate or lay eggs on his food.

In the fourth book, all of a sudden, the animals flee, and 
Gulliver notices that a horse has scared them out. Gulliver's hand repels the horse when he tries to touch him, and the horse refuses to let it contact him. A further horse is getting close. These all horse "polite" with everyone, according to Gulliver, and appear to communicate properly in unknown languages. Those are approached Gulliver and study and admire each piece of his attire with care. Gulliver deduces that perhaps the horses are magicians who may have transformed into horses. When he listens to them speak, he hears them say Yahoo, which he repeated. The horses are enamored with him and attempt to teach him the term Houyhnhnm. These are some of the horses' motions for Gulliver to following him.

Gulliver is led to a dwelling by this horse, and he prepares the toys and jewelry he usually packs to offer to native tribes. Gulliver continues to expect to hear a human talk as he is led in, so he wondering exactly what sort of master does all horses as attendants. Despite this, he observes no humans, simply a handful of horses tucked up in tidy chambers. Houyhnhnm used the only word that is Yahoo. These Yahoos used as humans clothes, politics, medicine, and game everything.

\section{Race and Landscape}

Swift's Anglo-Irishness is considered crucial to analyzing his temperament and works; information from his writings suggests that Swift had a split personality when it came to his sense of national identity, his attitude towards England and Ireland, and his thoughts on colonization. Swift was schizophrenic in that he was an anti-colonial colonialist who denounced the operation that he championed and benefitted from. With Swift's initial "Pamphlets" to "Gulliver's Travels" and A Modest Proposal, this problem culminated in a bifocal view of British colonialism in Ireland and colonialism in general. His intent on how to be considered as an Englishman can be seen in his early correspondence and works. His skills associated classification as that of an Irish person but by English, as well as his desire to distance himself from the majority of indigenous Irish, Swift hasn't ever related about himself or its protestant hegemony toward which he remained loyal as Irish or Anglo Irish; instead, he dismisses his Dublin born as a mishap and speaks of his tender filial affection for England, my dear native country, only rarely acknowledging that Ireland has a significant share in my love; and history repeatedly blames the English for their unawareness of Ireland and, in particular, for failing to distinguish between colonizers and colonized, English protestants and Irish epitasis in Ireland fight over it becoming labeled as an English or an Irishman, while also lamenting the injustices.

Gulliver's unwillingness to relegate 'Blefusc' to the rank of a Lilliputian provincial throughout book one, and also the Colonial operation carried out by the flying Island and fiercely avoided by the resilient people of Lindalino in book third, are both examples of swift denunciation of colonization. But, Gulliver's 4th adventure has been the most crucial in this sense, as Swift doubts any government's authority to take control of some other country in order of divine kingship by having Gulliver criticize the techniques employed to liberate the newly found country's inhabitants after the story. Gulliver's exoneration of the English countryside from such a responsibility, as well as his endorsement of its real methods as an example to the rest of the globe for their wisdom and justice in colonial colonization, is ludicrous. Gulliver's use of colonialism as a justification as long as it does for the benefit of religions and study, as well as the steps he suggests to assure proper colonialist governance, may reveal Swift's other imperialist side. All attempts to rationalize colonialism are, however, profoundly destroyed in the next statement.

"Gulliver's use of colonialism as a justification as long as it does for the benefit of religions and study, as well as the steps he suggests to assure proper colonialist governance, may reveal Swift's other imperialist side. All attempts to rationalize colonialism are, however, profoundly destroyed in the next statement".
Swift must have been able to reject colonialism explicitly in the fictitious world of Gulliver's Travels, yet even here that the unimportance of his Anglo Irish status could be felt in Gulliver's spinelessness between justifying and condensing colonial practices. Swift's issues about the Anglo-Irish identity, as well as colonialism, are at the center of the entire fourth book. Recent studies have revealed the native Irish Yahoo character in traditional and modern Writing skills, and also in Swift's writings. Considering the parallels with slave masters relation in Ireland and Houyhnhnmland, particularly the reasoning of coniferous, who stigmatize the colonized as bad, much like Swift did in regards to the Irish, and enslaved bestializes those locals. An absolute and unique association of Yahoos so much to an Irish, Houyhnhnms with England, and Gulliver to Swift an Anglo Irishman would have been restrictive because Swift was more interested in polysemous and ambiguities than in simplistic allegories. Even so, this same Irish-English relationship was traditionally viewed in England as an antithesis between barbarism and western civilization, evil and morality, ambition and logic, and, as Swift points out, the Anglo Irish must have been formed by that of the English with no more than the tincture of the season about Gulliver either by Houyhnhnms. Gulliver's identity crisis is akin to Swift's passionate but futile desire to be acknowledged as an Englishman, as well as his absolute hatred of being thrown into the barbarous Irish even by English, as well as his ensuing national identity schizophrenic.

Swift was enough to explore his colonial dilemma in the fictional guise of Gulliver among the Yahoos and the Houyhnhnms, where he was able to fully explore his identification with the idealized English slave Masters and also guilty complicity in the enslavement, degradation, and poverty of the Irish. Gulliver's recommendation that the yahoos whose be hunted down and killed and his use of Yahoo skin and tallow in the making of a scanner and its sale point to Swift's deep feeling of guilt over his part in destroying the Irish and trying to profit again from existing colonial system, whereas Swift usually closed his eyes to his role in bringing about the pain and suffering of the Irish. In the interpretation of a Swift psychic dilemma, his desire to annihilate his Irish may have been joined with a suppressed desire to see the Irish genuinely exterminated, which Swift converted into a pro-Irish humanitarian.

In the first book the skin color of Lilliputians so fair, aristocratic color, but in the second book the farmers' color was like peasant color and the farmer made Gulliver become a monkey in the local market shows the zoo culture and slave system. Once Gulliver entertains the king, every day tells about England, The king continues to explain that he may have discovered which England's clergy, armies, justices, and legislators are all unfit for office. He ends by noting how his experiences of Gulliver and Gulliver's unwillingness to answers his queries have taught him to believe Englishmen are true "a most poisonous breed of little ugly worms."

In the third book, he entered Laputian island and took permission from the Laputian monarch grants Gulliver permission to tour the island, which he describes as a fourand-a-half mile diameter circular with a layer of adamant just like its foundation and enormous magnets meeting the criteria in a chasm at the island's center. The amateur astronomers rotate the magnetism and as such the magnetic field attracting or repelling side approaches the bottom of the kingdom. The Laputian king governs the country further below controlling the island's movements. If a group of people is misbehaving, he hovers the island over them, blocking the sun and rain from reaching their territory. If they continue to misbehave, he will batter them with all of the stone down from the sky. As they continue to misbehave, he lowers the island over them, threatens to entirely crush them. The monarch, nevertheless, seems generally too concerned about destroying Laputa's base to desire to smash any area of his country, as the kingdom's subjects are well aware. 


\section{CONCLUSION}

Jonathan Swift's utilization of horses as humorous instruments in Gulliver's Travels has been explored by several critics. Nobody, unfortunately, has paid a lot of consideration to Swift's earlier "ecocriticism" awareness about animal issues related to humans. Even though the animal motif in Gulliver's Travels has humorous overtones, this study argues that it has deeper ramifications than reveal Swift's forward-thinking beliefs about the human-natural environment interaction, as embodied in the human-animal relationship. Swift emphasizes both openly and indirectly throughout the novel the ethical stand and moral commitment to the natural world represented by animals, as well as the concern for using the themes of a literary work to develop connections between man and the natural environment around him.

\section{REFERENCES}

1) Swift,Jonathan."Gulliver's Travels into several remote nations of the world". Release Date:February 20, 1997 [eBook\#829] [Most recently updated: May 18,2021]

2) Zach, Wolfgang. "Jonathan Swift and Colonialism." The Canadian Journal of Irish Studies, vol.26, no. 1,2000,pp.36-46.JSTOR.

3) Ortiz-Robles, M. (2016).Literature and Animal Studies (1st ed.).Routledge.https // doi.org/ 10.4324/9781315880389

4) Garrard, Greg.Ecocriticism, THE NEW CRITICAL IDIOM. This edition published in the Taylor \& Francis e-Library, 2004. 